\title{
III. Administrative Courts and Judicial Comparativism in Central and Eastern Europe
}

Joanna Krzemińska-Vamvaka*

\section{Introduction}

Administrative law is no longer what it used to be. Two major transformative forces shape it: the rise of global governance ${ }^{1}$ and the increased international cooperation and linkages. The international economic, social and political interdependence has led to the emergence of transnational laws and structures. In addition, national administrations and courts have been confronted with an increased number of cross-border cases.

* Dr iur.; Head of Unit in the Trade Defence Services of the Directorate General for External Trade, European Commission, Brussels. Views presented are personal views of the author. I am deeply indebted to the Latvian, Estonian and Hungarian Supreme Courts for their invaluable input and comments. I greatly benefited from discussions with Maria Javorova. I also appreciate the help of Alexei Trochev and Sergei Marochkin. Translations from Estonian: courtesy of Triin Pakkonen.

1 B. Kingsbury, N. Krisch, R. Stewart, 'The Emergence of Global Administrative Law' (Global Administrative Law Project 2005), <http://www.iilj.org/wp-content/uploads/2016/08/Kingsbury-etal-The-Emergence-of-Global-Administrative-Law-2004-2.pdf> (access: 17 May 2016) 17 ; see also more general on judicial dialogue A.M. Slaughter, 'A Global Community of Courts' (2004) 44 Harvard International Law Journal, p. 194. 
This contribution explores one aspect of how administrative courts respond to those new challenges. It deals with judicial comparativism, i.e. the practice whereby courts voluntarily decide to look at foreign law. ${ }^{2}$ The concept of judicial comparativism is broader than that of judicial dialogue and covers cases of voluntary judicial recourse to foreign law (legislation, case law, commentaries). It does not cover cases governed by foreign law under the choice of law rules of the forum State. Judicial comparativism is also not limited to instances of judicial dialogue where national courts refer to foreign judgments, i.e. engage in a dialogue with foreign courts.

\section{Cases with a Foreign Element}

It is difficult to find comparative judgments in the case law of administrative courts. It proves much more difficult than searching the databases of Constitutional Courts. ${ }^{3}$ Not only do administrative courts typically have a very high exposure to cases with cross-border elements, but the mere number of judgments of administrative courts is a challenge in itself.

The exposure to cases with a foreign element is difficult to measure. A search in the database of the Polish administrative courts gives some indications. A search based on a selected country names yields a high number of results (in the tune of 20000$){ }^{4}$ By way of comparison, the same search performed in the database of the Polish Constitutional Court yields a list of around 500 judgments. A similar observation is also true for other countries. ${ }^{5}$ To identify comparative judgments from among such a high number of cases is particularly challenging.

2 J. Krzeminska-Vamvaka, 'Courts as Comparatists: References to Foreign Law in the case-law of the Polish Constitutional Court' (2012) Jean Monnet Working Paper 05/12, <http://www. jeanmonnetprogram.org/wp-content/uploads/2014/12/JMWP05Krzeminska-Vamvaka.pdf> (access: 17 May 2016) 2.

3 This conclusion is based predominantly on research conducted for J. Krzeminska-Vamvaka, ibidem.

4 For example, a search for 'Germany' returns 14727 judgments. A search for 'France' returns 3281 judgments. A search for 'Italy' - 1161 judgments. A search for 'UK' - 3561. A more targeted search with names of foreign courts, notably highest courts, yields a much more limited number of judgments. The representativity of such a search, however, would be limited as would have left out references to foreign legislation, scholarship or those simple references to a country by its name. It would also not account for those instances where the comparing court does not precisely follow a method of quotation in the legal system to which it refers.

5 In Slovakia, a search in the database of the Supreme Court for 'France' yields a result of 1091 judgments, a search for 'cour' - 476 judgments. 
The research for this paper involved a detailed search in the database of the Polish administrative courts for the years 2010-2014. ${ }^{6}$ The comparative analysis is based on information from a number of countries: Estonia, Lithuania, Latvia, Hungary, and Russia.

\section{The EU Administrative Law and Judicial Comparativism}

While judicial comparativism is not an EU phenomenon, the EU law is an excellent foundation for the development of an intense judicial dialogue. In fact, the research conducted for the purposes of this paper shows that the Polish administrative courts refer to law of other EU Member States ('MS') often in the context of application of EU law.

The general principle of implementing Union law is that of indirect administration. ${ }^{7}$ Apart from few instances of direct application by EU institutions (e.g. competition ${ }^{8}$ ), the task of implementing Union law lies predominantly with the EU Member States. ${ }^{9}$ In some instances the EU legislator will entrust the Commission with the direct management of some provisions or adoption of implementing rules to ensure uniform and consistent application..$^{10}$ The European administrative law ${ }^{11}$ encompasses both the administrative law rules related to the application of Union law by the EU institutions, as well as national rules for the application of Union law by the MS.

The particular set up of the EU, with the overarching principle of uniform application of Union law and the interdependence between MS' systems of administrative law, lays excellent foundations for the judicial dialogue between EU

6 Baza orzeczeń Naczelnego Sądu Administracyjnego [Case Law Database of the Supreme Administrative Court] <http://orzeczenia.nsa.gov.pl> (access: 17 May 2016).

7 J.C. Piris, The Lisbon Treaty. A Legal and Political Analysis (Cambridge University Press 2010), p. 97.

8 Articles 105 and 106 of the Treaty on the Functioning of the European Union (TFEU), as well as Art. 108 TFEU.

9 Article 4(3) of the Treaty on the European Union states that the MSs shall take any appropriate measures, general or particular, to ensure fulfilment of the obligations arising out of the Treaties or resulting from the acts of the institutions of the Union. Article 291(1) TFEU states that MSs shall adopt all measures of national law necessary to implement legally binding Union acts.

10 J.C. Piris (n. 7), p. 98.

11 See: J. Schwarze, Europaeisches Vervaltungsrecht (Nomos 2005); P. Craig, EU Administrative Law (Oxford University Press 2012); J.B. Auby, J.D. de la Rochere, Traité de droit administratif europée (Bruylant 2014). 
administrative courts. Indeed, administrative law in Europe has been converging for quite a while now. ${ }^{12}$ This convergence comes about due to the role played by the EU Court of Justice ('CJEU') but also to MSs voluntarily extending Union standards to purely domestic situations. ${ }^{13}$

Much has been happening in the area of administrative procedure. In 2010, the European Parliament's Committee on Legal Affairs founded a Working Group on EU Administrative Law. ${ }^{14}$ The Group's task was to take stock of the body of the existing EU administrative law and, possibly, propose legislative interventions. Following the work of the Group, in 2013, the European Parliament adopted a resolution requesting the European Commission to submit on the basis of Article 298 of the Treaty on the Functioning of the European Union (TFEU) a proposal for a regulation on European Law of Administrative Procedure. ${ }^{15}$ In 2014, a research network on EU administrative law (Reneual) published its model rules on administrative procedure, ${ }^{16}$ supported by the European Ombudsman. ${ }^{17}$ Furthermore, in 2012, Reneual joined forces with the European Law Institute and started to work on a joint project "Towards Restatement and Best Practices Guidelines on EU Administrative Procedural Law." The objective of the cooperation is to steer the debate on European administrative procedural law as well as to develop restatements and best practices, which could be transformed into legislative proposals. ${ }^{18}$

12 See: 'Developing administrative law in Europe: Natural convergence or imposed uniformity?' (Conference proceedings, the Hague, 29 November 2013), <http://www.aca-europe.eu/index.php/en/evenements-en/443-the-hague-29-november-2013-seminar-developing-administrative-law-in-europe-natural-convergence-or-imposed-uniformity> (access: 17 May 2016).

13 R.J.G.M. Widdershoven, 'Developing administrative law in Europe: Natural convergence or imposed uniformity? Setting the Scene: Introduction and Aim of the Seminar', <http://www. aca-europe.eu/seminars/DenHaag2013/Introduction_Widdershoven.pdf> (access: 17 May 2016).

14 Working Group on EU Administrative Law, 'Working Document, State of Play and Future Prospects for EU Administrative Law' (European Parliament), <http://www.europarl.europa.eu/ document/activities/cont/201210/20121025ATT54550/20121025ATT54550EN.pdf> (access: 17 May 2016).

15 European Parliament, 'Resolution of 15 January 2013 with recommendations to the Commission on a Law of Administrative Procedure of the European Union (2012/2024(INL))', <http:// www.europarl.europa.eu/sides/getDoc.do?type=TA\&reference=P7-TA-2013-0004\&language=EN\#BKMD-4> (access: 17 May 2016).

16 Research Network on EU Administrative Law Homepage <http://www.reneual.eu/> (access: 17 May 2016).

17 Research Network on EU Administrative Law, 'Reneual Model Rules on EU Administrative Procedure, Foreword by the European Ombudsman', <http://www.reneual.eu/images/Home/ forewordeuombudsman.pdf> (access: 17 May 2016).

18 European Law Institute, 'Towards Restatement and Best Practices Guidelines on EU Administrative Procedural Law', <https://www.europeanlawinstitute.eu/projects/current-projects-contd/article/towards-restatement-and-best-practices-guidelines-on-eu-administrative-procedural-law-1/?tx_ttnews[backPid] $=137874 \& \mathrm{cHash}=6 \mathrm{c} 603409 \mathrm{~d}$ 6765725530b3ab7bfd06b9d> (access: 17 May 2016). 
There is thus an on-going process of convergence of administrative law in Europe: top down, bottom up, structured or spontaneous. It is linked to national application of Union law but goes also beyond that context to purely domestic situations. The EU triggers a perception of belonging to one legal culture and it prompts EU courts to cooperate. This paper will explore how the process of convergence of the European administrative law influences judicial cooperation in Europe and how it manifests itself, in particular, in Central and Eastern Europe ('CEE'). It is mainly concerned with the formal framework and statistical overview of such cooperation.

\section{The Cooperation of Administrative Courts and Judges in the EU}

The European administrative judges cooperate and interact in the framework of two major European associations: Association of the Councils of State and Supreme Administrative Jurisdictions of the European Union ('ACA') ${ }^{19}$ as well as Association of European Administrative Judges ('AEAJ'). ${ }^{20}$ Another important association is the Network of the Presidents of the Supreme Judicial Courts of the European Union. ${ }^{21}$

The interaction principally takes the form of periodic meetings, often dedicated to specific issues (asylum, sources of law, administrative justice, E-justice). AEAJ's cooperation is divided largely into four main thematic blocks (asylum-immigration, environmental law, independence-efficiency and taxation).

This structured cooperation of judges, i.e. such that takes place within the framework of judicial organizations, constitutes a form of judicial dialogue. It is also present in other areas of law or cross-cutting different areas (Conference of European Constitutional Courts, ${ }^{22}$ Network of the Presidents of the Supreme Judicial Courts of the European Union (the Network of the

19 The Association of the Councils of State and Supreme Administrative Jurisdictions of the European Union <http://www.aca-europe.eu/index.php/en> (access: 17 May 2016).

20 The Association of European Administrative Judges Homepage <http://www.aeaj.org> (access: 17 May 2016). Other organizations include the European Union Forum of Judges for the Environment <http://www.eufje.org/index.php/en/> (access: 17 May 2016).

21 The Network of the Presidents of the Supreme Judicial Courts of the European Union Homepage <http://www.network-presidents.eu/> (access: 17 May 2016).

22 Conference of European Constitutional Courts Homepage <http://www.confeuconstco.org/ home.html> (access: 17 May 2016). 
Presidents ${ }^{23}$ ). Some aspects of judicial cooperation have also been formalized under the auspices of the EU (Eurojust, ${ }^{24}$ European Judicial Network in Civil and Commercial Matters, ${ }^{25}$ European Judicial Network in Criminal Matters $^{26}$ ), or the Council of Europe (the European Commission for Democracy through Law, known as Venice Commission, ${ }^{27}$ the European Commission for the Efficiency of Justice, ${ }^{28}$ Consultative Council of European Judges $\left.{ }^{29}\right)$. Finally, some organizations focus on international training for judges (International Organization for Judicial Training, ${ }^{30}$ as well as the European Judicial Training Network $\left.{ }^{31}\right)$. On the UN level in 1994 the Commission on Human Rights appointed a Special Rapporteur on the Independence of Judges and Lawyers, who monitors the independence of the judiciary, ${ }^{32}$ especially in view of the Ba-

23 The Network of the Presidents of the Supreme Courts <http://www.network-presidents.eu/> (access: 17 May 2016).

24 See: Eurojust Homepage<http://eurojust.europa.eu/Pages/home.aspx> (access: 17 May 2016) and <http://eurojust.europa.eu/about/legal-framework/Pages/eurojust-legal-frame $\neg$ work. aspx> (access: 17 May 2016). Eurojust stimulates and improves the co-ordination of investigations and prosecutions between the competent authorities in the Member States.

See: The European Judicial Network in civil and commercial matters Homepage <http:// ec.europa.eu/civiljustice/index_en.htm> (access: 17 May 2016). The European Judicial Network in civil and commercial matters (EJN-civil) is a flexible, non-bureaucratic structure, which operates in an informal mode and aims at simplifying judicial cooperation between the Member States.

26 See: A network of national contact points for the facilitation of judicial co-operation in criminal matters <http://www.ejn-crimjust.europa.eu/ejn> (access: 17 May 2016).

27 See: The Venice Commission Homepage <http://www.venice.coe.int> (access: 17 May 2016). The Venice Commission is the Council of Europe's advisory body on constitutional matters. Established in 1990, it has played a leading role in the adoption of constitutions that conform to the standards of Europe's constitutional heritage. Initially conceived as a tool for emergency constitutional engineering, it has become an internationally recognised independent legal think-tank. Today it contributes to the dissemination of the European constitutional heritage, based on the continent's fundamental legal values while continuing to provide 'constitutional first-aid' to individual states.

28 See: The European Commission for the Efficiency of Justice Homepage <http://www.coe. int/T/dghl/cooperation/cepej/default_en.asp> (access: 17 May 2016). The aim of the CEPEJ is the improvement of the efficiency and functioning of justice in the member states, and the development of the implementation of the instruments adopted by the Council of Europe to this end.

29 See: The Consultative Council of European Judges Homepage <http://www.coe.int/t/DGHL/ cooperation/ccje/default_en.asp> (access: 17 May 2016). The Consultative Council of European Judges is an advisory body of the Council of Europe on issues related to the independence, impartiality and competence of judges. It is the first body within an international organization to be composed exclusively of judges.

30 The International Organization for Judicial Training Homepage <http://www.iojt.org > (access: 17 May 2016).

31 The European Judicial Training Network Homepage<http://www.ejtn.eu/> (access: 17 May 2016).

32 See: UNHCR, 'Issues: the Judiciary', <http://www2.ohchr.org/english/issues/judiciary> (access: 17 May 2016); see in particular UNHRC, Res 8 (2006), <http://ap.ohchr.org/documents/E/ HRC/resolutions/A_HRC_RES_8_6.pdf> (access: 17 May 2016). 
sic Principles on the Independence of the Judiciary. ${ }^{33}$ Another initiative is the Judicial Integrity Group ${ }^{34}$ whose aim is to strengthen the integrity of the judicial systems and which elaborated the, so-called, Bangalore Principles of Judicial Conduct. ${ }^{35}$

It is, however, not possible to measure the impact of the structured judicial cooperation on the application of domestic law in concrete cases. The endorsement of transnational cooperation can be deduced from public communications made by different courts (notably on their websites) and active participation in international forums.

The courts often publicly stress their involvement in international relations with other courts. The Polish Supreme Administrative Court reports in detail on international contacts and visits (events, conferences, topics covered). ${ }^{36}$ The Estonian Supreme Court lists all the international associations of which it is a member. ${ }^{37}$ Similar information can be found on the website of the Curia of Hungary ${ }^{38}$ and the Slovakian Supreme Court. ${ }^{39}$ The Latvian Supreme Court describes how it joined the European judiciary. ${ }^{40}$ The Lithuanian Supreme Administrative Court presents a detailed list of all international events, principally international conferences, in which the Lithuanian judges participated. ${ }^{41}$ Judges cooperate also in the framework of specific programs together with the academia. For example, the Centre for Judicial Cooperation at the European University Institute conducts research on judicial dialogue and targeted training sessions. ${ }^{42}$

33 Basic Principles on the Independence of the Judiciary <http://www.ohchr.org/EN/Professionallnterest/Pages/IndependenceJudiciary.aspx> (access: 17 May 2016).

34 The Judicial Integrity Group <http://www.judicialintegritygroup.org/index.php/jig-group> (access: 17 May 2016).

35 The Bangalore Principles of Judicial Conduct <http://www.judicialintegritygroup.org/index. php/jig-principles> (access: 17 May 2016).

36 The Polish Supreme Administrative Court Homepage, 'Współpraca Międzynarodowa', <http:// www.nsa.gov.pl/wspolpraca-miedzynarodowa-1.php> (access: 17 May 2016).

37 The Estonian Supreme Court Homepage <http://www.riigikohus.ee/?id=1291> (access: 17 May 2016).

38 The Curia Homepage, 'International Relations', <http://www.lb.hu/en/english/international-relations> (access: 17 May 2016).

39 The Slovakian Supreme Court Homepage, 'International activities', <http://www.nssr.gov.sk/ international-activities/> (access: 17 May 2016).

40 The Latvian Supreme Court Homepage, 'Joining the European Judiciary', <http://at.gov.lv/ en/the-history/joining-the-european-judiciary/> (access: 17 May 2016).

41 The Lithuanian Supreme Administration Court, 'The National and International Cooperation', $<$ http://www.lvat.lt/en/national-and-international-cooperation.html > (access: 17 May 2016).

42 European University Institute, Centre for Judicial Cooperation Homepage <http://www.eui. eu/Projects/CentreForJudicialCooperation/Home.aspx> (access: 17 May 2016). For details on methodology see the 'Methodology' section, <http://www.eui.eu/Projects/CentreForJudicialCooperation/MethodologyandResearch/Index2.aspx> (access: 17 May 2016). 


\subsection{Sharing of Comparative Information}

Besides meetings, the associations also enable and facilitate exchange of comparative information. In particular, ACA, AEAJ, the Network of Presidents, run on their websites databases of national case law..$^{43}$ Those databases principally serve as platforms for exchange of case law and information on the national application of EU law.

The ACA's Dec.Nat. database contains national decisions related to preliminary rulings. It is based on resources of national decisions maintained by the CJEU's Research and Documentation Department. ACA developed an interface for public web consultation of the database in English and French.

The ACA's JuriFast database (the fast information system for case law) contains references to preliminary questions of national courts and the national court's decisions following the CJEU's answer. The database also contains other national decisions on the interpretation of EU law. It is fuelled directly by the Research and Documentation Centres of the ACA members (Supreme and Supreme Administrative Courts).

The Network of the Presidents of the Supreme Judicial Courts of the European Union has also a portal of national case law. It goes beyond administrative law and is a search engine of national case law that simultaneously queries several national search engines.

The ACA's newsletter is another medium of sharing comparative information. ${ }^{44}$ Practicing judges present topical issues from the viewpoint of national and EU legislation. Through its website, ACA also makes available the CJEU's Reflets (publication on legal development of interest to the European Union, including commentary of the national case law). ${ }^{45}$

The project of the Centre for Judicial Cooperation has a database of national decisions. ${ }^{46}$ It gathers case law from 19 jurisdictions, across different areas of law, but with the common denominator of reference to the Council of Europe's Convention on Human Rights and Fundamental Freedoms (ECHR) or the Charter of Fundamental Rights of the EU (CFR).

Of course, the success of sharing the comparative information is only as good as the continuous involvement of individual courts and judges. In fact, ACA

43 See for instance: The Network of the Presidents of the Supreme Judicial Courts of the European Union, 'Common portal of case law', <http://network-presidents.eu/rpcsjue> (access: 17 May 2016).

44 Association of Councils of States and Supreme Administrative Jurisdictions, 'Newsletter', <http://www.aca-europe.eu/index.php/en/newsletter-en> (access: 17 May 2016).

45 Association of Councils of States and Supreme Administrative Jurisdictions, 'Reflets', <http:// www.aca-europe.eu/index.php/en/reflets-en> (access: 17 May 2016).

46 European University Institute Centre for Judicial Cooperation, 'Case Law Database', <http:// www.eui.eu/Projects/CentreForJudicialCooperation/CJCDatabase/Database.aspx> (access: 17 May 2016). 
identified lack of contributions as one of the biggest risks for the development of its JuriFast database. Figure 1 below illustrates the number of contributions per member country: ${ }^{47}$

Fig. 1. The number of contributions per member country

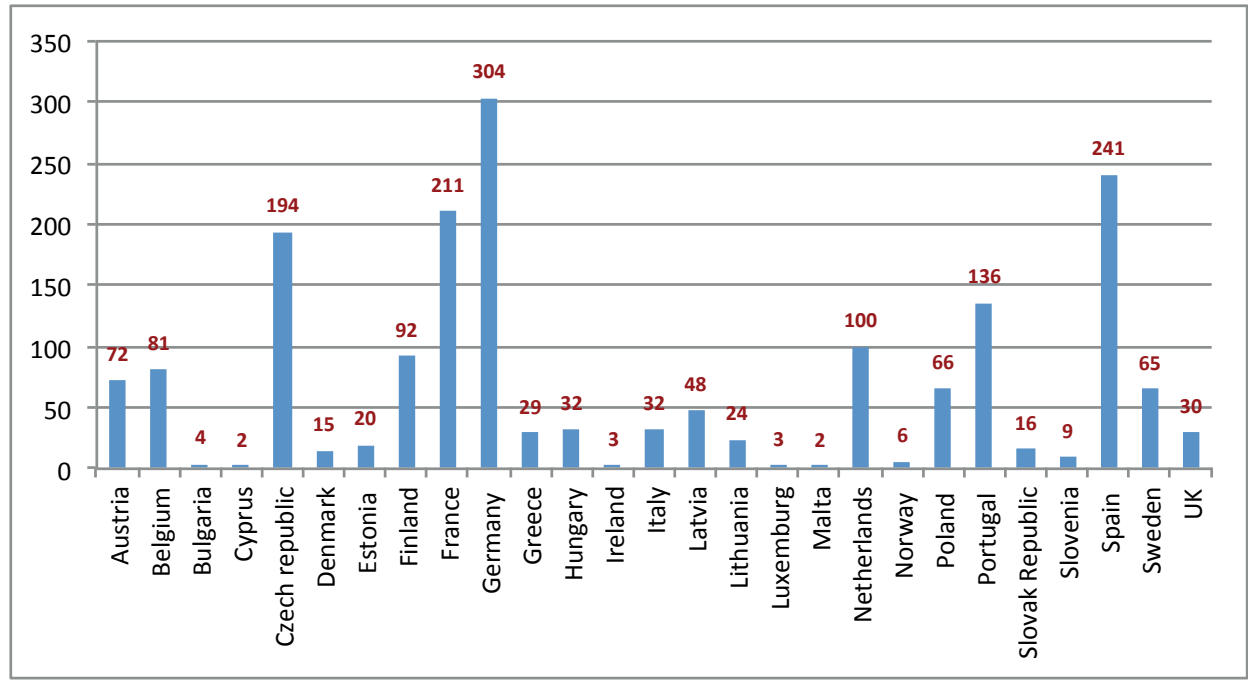

While the data presented in the figure above has to be set against the background of the size of the country (number of inhabitants influencing the number of court cases), it does give a fairly reasonable view of contributions per member country.

Fig. 2. The number of annual entries by the courts

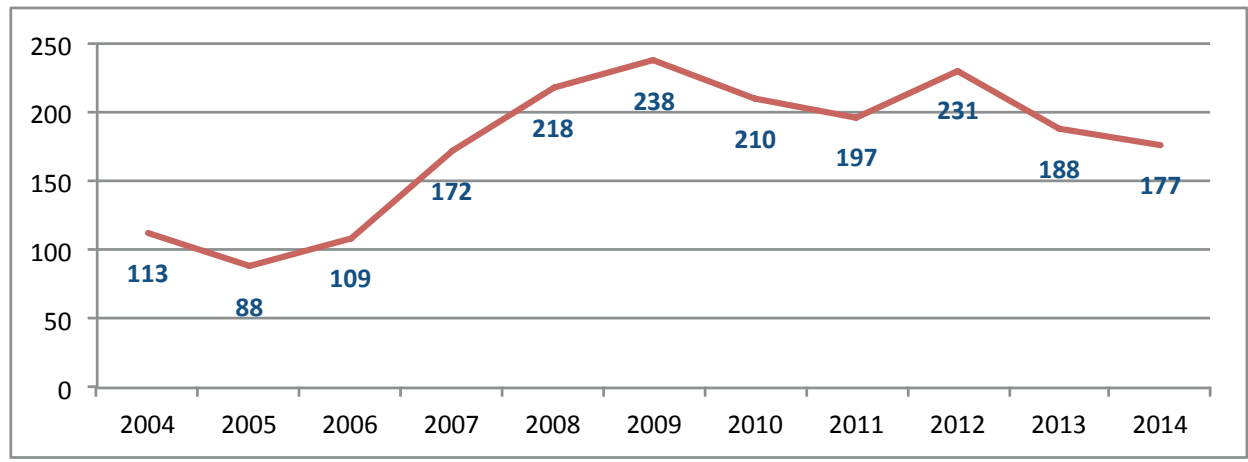

47 Data as for 21 April 2015. 
The comparative aspect of the database is also visible in the share of entries not related to preliminary rulings. Out of 1837 entries, 1408 do not concern preliminary rulings $(76 \%){ }^{48}$

The mere fact that courts actively participate and continuously feed the database, in itself, proves that there is an interest in transnational cooperation and exchange. Indeed, the number of annual entries by the courts has been steadily growing:

ACA measured the success of the JuriFast database by the number of visits to the website (3069 in 2014 from 2698 in 2013, increase by $14 \%$ in just one year). ${ }^{49} \mathrm{ACA}$ considers that the success was due to the timely uploading of the decisions directly by the courts and the direct access by users. ${ }^{50}$ Despite some quality issues, the database is a success. This is also due to the fact that national courts provide information in English or French, including summaries of decisions.

The access to national decisions as well as personal or institutional contacts between judges are key for a successful development of judicial dialogue. Language plays an important role in enabling access, so the summaries of decisions are extremely important. However, a summary is always just a first step to a more in-depth analysis embedded in a broader context of a particular legal system. The access to full decisions of national courts in English or French is difficult to obtain. While some landmark decisions will always be available (even on the websites of national courts), the on-going structured cooperation is key for fast access to the best sources of information. Databases created by the different organizations of judges are the best sources of information on a particular case or a legal provision, but also the most efficient way to obtain a broader view of a particular legal system. Those two elements are necessary for a methodologically sound comparative approach.

\subsection{Internet-Enabled Continuous Communication}

ACA has also developed another - more dynamic, instant and direct - communication tool. It is the ACA-Europe Information Network (ACA Forum). It is a password-protected system available to judges only: an immediate and spontaneous communication tool between judges. ${ }^{51}$

The communication takes place within two major channels: a direct on-line and via the so-called national correspondents. The first channel operates as

48 Data as for 21 April 2015.

49 E. Thibaut, 'Presentation of the JuriFast Project', <http://www.aca-europe.eu/seminars/2014_Brno/RT2_JuriFast_THIBAUT_EN.pdf> (access: 17 May 2016), p. 4.

50 Ibidem, p. 5.

51 ACA-Europe Information Network Proposed operating process for the ACA Forum <http:// www.aca-europe.eu/seminars/2014_Brno/RT1_Dutheillet\%20-\%20Forum_EN.pdf> (access: 17 May 2016). 
a typical on-line forum. Participants can engage in exchanges on specific topics. The second channel is coordinated by the so-called national correspondents who ensure that questions posed to their court are replied to in a timely manner.

It appears, however, that the Forum was not fully utilized due to time constraints on the part of the judges to respond to queries from abroad. ${ }^{52}$

\subsection{Exchange Programs for Practicing Judges}

ACA organizes also short-term exchange programmes for judges to participate in activities of a court in another Member State. Guest judges attend hearings, take part in deliberations and assist in writing judgments.

Fifty-seven judges so far participated in the exchange program. While the number is small in relation to the total number of judges, the comparative and EU aspects of the exchange are very telling. All judges appreciated the opportunity to get acquainted with foreign legal systems. Interestingly, each judge has to identify a practice in the host institution, which s/he would like to 'export' to their home country. Those mainly relate to organizational matters but judges discuss also in detail substantive or procedural law of the host country. According to one report, the comparative aspect of the exchange provides a fresh viewpoint of the home administrative law and contributes to approximation of legal standards in Europe. It also ensures uniform application of EU law.

The level of participation by CEE countries in the exchange programme is overall low, both in terms of hosting a judge from another country as well as in terms of sending a judge to complete a program in another country. From among 57 judges, 14 came from the CEE countries (24\%). Only 6 of the 57 judges (10\%) decided to complete their exchange program in a court of a CEE country (Hungary, Czech Republic, Slovenia, Poland).

All judges that completed the ACA exchange program expressed very positive views about the advantages of the comparative experience for their domestic practice. Those opinions are indeed very telling. In fact, the collection of exchange reports on the ACA's website is probably the best available tribute to judicial dialogue coming from practicing judges.

\subsection{The Structured Cooperation as a Backbone of Judicial Comparativism}

There are two main objections against the use of judicial comparativism. One is that judges lack knowledge about the legal system they refer to and simply cherry-pick provisions of foreign law they refer to. The other objection pertains to social, political, cultural, economic and historical differences between countries.

52 L. Záhradníková, 'The Forum: Shared Pool of Information Round Table', <http://www.aca-europe.eu/seminars/2014_Brno/RT1_Forum_LUCIA.pdf> (access: 17 May 2016). 
For example, in the U.S., judicial comparativism is sometimes described as undemocratic because "[j]udges in foreign countries do not have the slightest democratic legitimacy in a U.S. context." ${ }^{33}$ The fear is that judges would be selective and potentially arbitrary in their choices of foreign law. ${ }^{54}$ Because of the lack of normative framework such 'cherry-picking' could lead to disregarding social, political, cultural, economic and historical differences between countries. Disregard of such broader context in which law operates is the main objection to judicial comparativism. A related argument is that national judges are largely unaware of those complex social, political, cultural, economic and historical backgrounds behind decisions of their foreign counterparts. ${ }^{55}$ Richard Posner states that

[t]o know how much weight to give a decision of the German Constitutional Court in an abortion case, one would want to know such things as how the judges of that court are appointed, how they conceive of their role, and, most important and most elusive, how German attitudes toward abortion have been shaped by peculiarities of German history, notably the abortion jurisprudence of the Weimar Republic, thought to have set the stage for Nazi Germany's program of involuntary euthanasia. ${ }^{56}$

While the socio-economic and political differences are important, they should not overwhelm the comparative activity. They have to be identified, acknowledged and taken into account. Montesquieu was also one of the advocates of such holistic approach to comparative activity of judges. While he warned against the use of foreign law on account of socio-political, economic and other differences between States, ${ }^{57}$ he insisted that comparisons should consider legal

53 R.A. Posner, 'Foreword: A Political Court' (2005) 119 Harvard Law Review, p. 31.

54 J. Waldron, Partly Laws Common to All Mankind: Foreign Law in American Courts (Location 4130 of 8217, Kindle Edition, Yale University Press 2012); B. Markesinis, J. Fedtke, Judical Recourse to Foreign Law. A New Source of Inspiration? (Routledge 2007), p. 61.

R.A. Posner (n. 53), p. 86; for a summary of the problem of cultural differences between legal systems see: P. de Cruz, Comparative Law in a Changing World ( $3^{\text {rd }}$ Edition, Routledge-Cavendish 2007), p. 222.

56 R.A. Posner (n. 53), p. 86.

57 "[Laws] should be adapted in such a manner to the people for whom they are framed that it should be a great chance if those of one nation suit another. They should be in relation to the nature and principle of each government [...]. They should be in relation to the climate of each country, to the quality of its soil, to its situation and extent, to the principal occupation of the natives, whether husbandmen, huntsmen, or shepherds: they should have relation to the degree of liberty which the constitution will bear; to the religion of inhabitants, to their inclinations, riches, numbers, commerce, manners, and customs." C. de Secondat (Baron de Montesquieu), The Spirit of Laws (Kindle Edition, Location 251-259 of 10328, Halcyon Classic Series 1752); Waldron (n. 54), Location 4254 of 8217; O. Khan-Freund, 'On Uses and Misuses of Comparative Law' (1974) 37 Modern Law Review, p. 27; M. Tushnet, 'The Possibilities of Comparative Constitutional Law' (1999) 108 Yale Law Journal, p. 1225. 
systems "in their entirety." ${ }^{58}$ Comparativists should duly consider differences between legal systems that affect comparability. However, such differences are not as such a 'conversation stopper' in the discussion on judicial comparativism. ${ }^{59}$ While there is a clear need for methodological standards for comparative activity, the requirements should not be overwhelming but reasonable for a non-native lawyer.

The structured cooperation in all its manifestations and forms, as discussed above, is key to overcome the methodological difficulties of comparative activity. The ongoing, structured cooperation is a source of information on particular decisions, legislation, and background information about the legal system as well as socio-economic and political aspects that need to be considered.

\subsection{The CEE Cooperation}

There is no structured cooperation between the CEE administrative courts or judges beyond the pan-European cooperation. Since the cooperation of EU courts is linked predominantly to the exchange of experiences and best practices with regard to the application of EU law, the CEE courts joined the existing European associations.

However, there are examples of some bilateral CEE cooperation. The Polish Supreme Administrative Court, for example, organizes regular workshops with the Czech administrative judges. ${ }^{60}$ The Romanian High Court of Cassation and Justice mentions on its website cooperation with Moldova. ${ }^{61}$ These examples are very rare and insignificant compared to the extent of the pan-European cooperation.

It is indeed surprising that the cooperation between CEE courts and judges is so limited. Since the CEE countries share a common recent history, one could assume that the ties between them would be tighter. These countries went through the process of rebuilding their democracies and market economies as well as legislative overhauls to harmonize their legislation with the EU requirements. And yet, it would seem that their focus and attention is concentrated on the established, influential legal systems of Europe. Indeed, the empirical data paints a legal landscape of Europe where powerful centres of legal thought (Germany, France) provide inspiration to individual CEE countries. There

58 "Wherefore, to determine which of those systems is most agreeable to reason, we must take them each as a whole and compare them in their entirety." Montesquieu, ibidem, Kindle Edition, Location 8627 of 10328. Waldron (n. 54), Kindle Edition, Location 4260 of 8217.

60 The Polish Supreme Administrative Court, 'Grupy Robocze', <http://www.nsa.gov.pl/ grupy-robocze-sedziow.php> (access: 17 May 2016).

61 High Court of Cassation and Justice in Romania, International Cooperation Relations and Programmes <http://www.scj.ro/en/693/International-cooperation-relations-and-programs> (access: 17 May 2016). 
is not much (at least not much accessible) evidence of cooperation, or experience-sharing between the CEE countries. And yet they are exposed to one of the biggest dangers of applying comparative method in developing or shaping their legal systems.

The countries in transition that rebuild their legal systems often accept solutions adopted in other countries (especially in the Western established democracies) at face value, without the necessary scrutiny of the context. They face the risks identified by Günter Frankenberg who claimed that comparatists often fail to properly distance themselves from their own legal system and either perceive the other legal system through the lenses of their own or over-identify themselves with the compared legal system. Günter Frankenberg stated that "[a]s long as we understand foreign places as like or unlike our own, we cannot begin to fully appreciate them." ${ }^{62}$ According to Frankenberg, comparatists have to engage in an inner dialogue to reconcile the new and the settled knowledge whereby their respective claims to completeness and truth are "mutually questioned and tested." ${ }^{3}$ Günter Frankenberg claims that comparisons are guided and controlled by the comparatist's home legal system: “[ $t$ ]he comparatist's own 'system' is never left behind or critically exposed in the light of the new [...]. The comparatist travels strategically, always returning to the ever present and idealized home systems: Other societies or legal systems are 'not yet' developed, but may be considered on their way." ${ }^{4}$ Those thoughts are echoed by other authors who postulate that comparatists should always free themselves from any preconceptions based on their native system. ${ }^{65}$

The 'Frankenberg's comparatists' from established legal systems and those from the CEE countries face different challenges. The former would be more inclined to perceive the foreign legal systems through the 'domestic lenses'. The latter, on the other hand, face the reverse problem of over-identifying themselves with the foreign legal system and accepting foreign models at face value without adapting them to local conditions. While the CEE countries individually drew inspiration from the established centres of legal thought, like Germany or France, they faced the same challenge of rebuilding their legal systems. They could potentially share valuable experiences of how to introduce new solutions and adapt them to local conditions. While the CEE countries refer to foreign law as a source of inspiration or legitimization, they face a similar challenge of striking a balance between reliance on Western models and building national self-identity.

62 G. Frankenberg, 'Critical Comparisons: Re-thinking Comparative Law' (1985) 26 Harvard International Law Journal, pp. 411-412.

63 Ibidem, p. 413.

64 Ibidem, p. 433.

65 K. Zweigert, H. Koetz, Introduction to Comparative Law (Clarendon Press, Oxford 1998), p. 35. 


\section{The Overview of the References to Foreign Law by the Polish Administrative Courts}

The results of the empirical analysis of comparative judgments (those with any type of reference to foreign law) of the Polish administrative courts for the years 2010-2014 are difficult to analyse. Overall, there is quite a number of comparative judgments and they have been increasing between 2010 and 2014. In absolute terms, they increase from 24 comparative judgments in 2010 to 106 in 2013 and 72 in 2014. The increase between 2010 and 2013 is the most pronounced. It is less pronounced between 2010 and 2014: a drop from 24 comparative judgments to $72 .{ }^{66}$

Fig. 3. Comparative judgments $2010-2014$

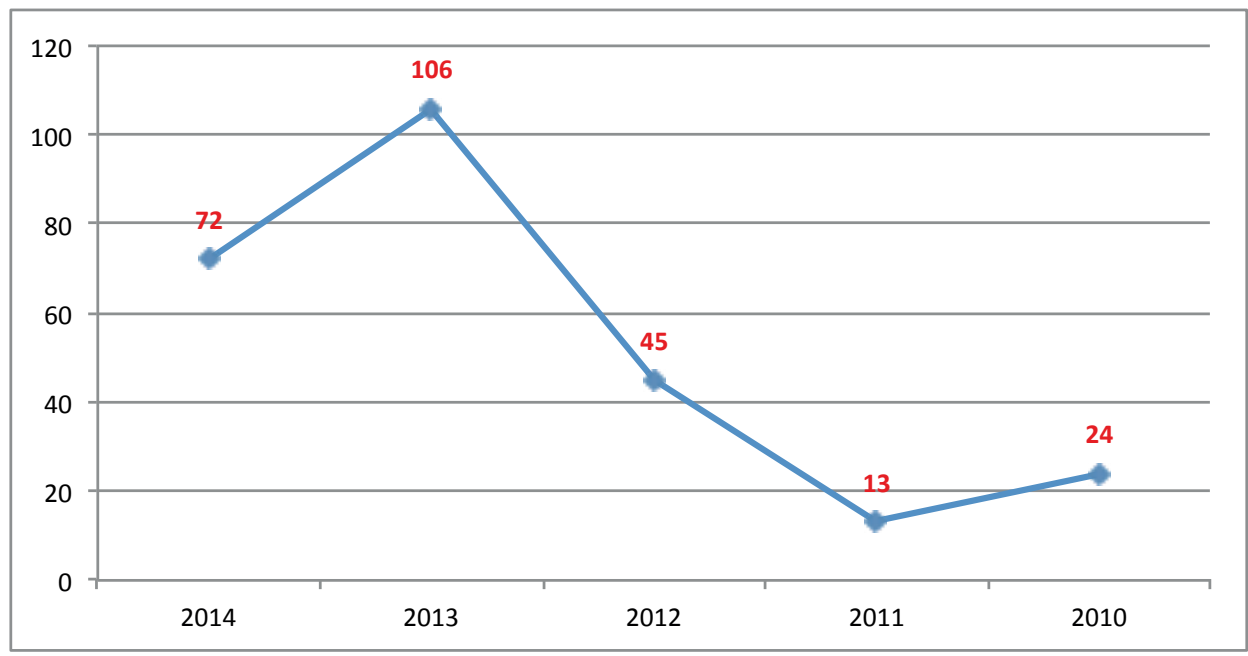

However, many of the comparative judgments are repetitive. They are based on similar facts and so repeat the exact same references to foreign law. In an attempt to better reflect the comparative activity of the courts, another set of data demonstrates only those judgments with original reference, without repetitions.

This set of data paints a mixed picture in terms of trend of comparative judgments. They are at roughly the same level in 2010 and 2011, 13 and 12 respectively.

66 Other countries not included in the graph are the following: Italy (19), Portugal (41), the UK (21), USA (5), Japan (3), Denmark (70), Malta (63), Montenegro (63), Czech Republic (14), Ireland (12), Canada (1), Austria (33), Romania (1), Serbia (1), Australia (7), Cyprus (18), Argentina (1), Malaysia (1), China (1), Spain (10), Greece (8), Luxemburg (9), Slovakia (2). The figures are based on a very detailed search of the database of the case law of the Polish administrative courts but a small margin of error cannot be excluded. 
They raise between 2011 and 2012 from 12 to 18 to then fall again to 15 in 2013 and only 6 in 2014.

Fig. 4. Comparative judgments $2010-2014$

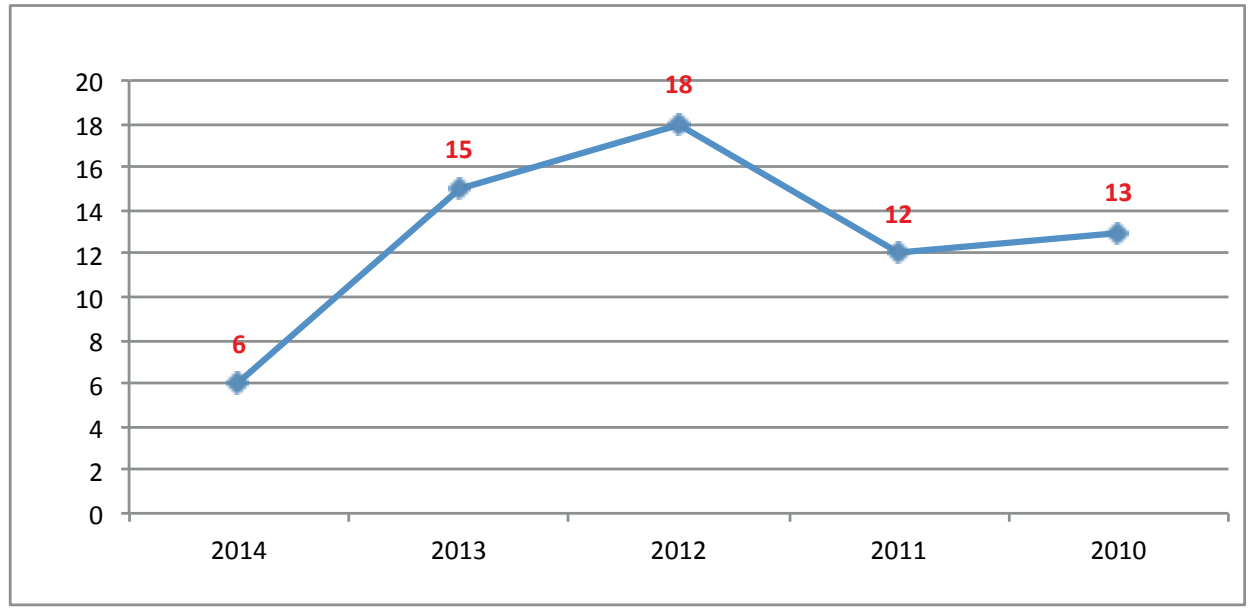

The most characteristic feature of the comparative activity is that in the vast majority of cases judges make references to multiple jurisdictions. Figure 5 below shows the number of references per country. If all references are included, Germany is the most frequent country of reference. Other top countries include Belgium, Finand, Hungary, The Netherlands, Sweden, Latvia, Bulgaria, France. ${ }^{67}$

However, the problem of repetitive references affects also the dataset illustrated in the figure above and the exclusion of repetitive references paints a different picture. Germany is still the top country of reference but it is closely followed by France, then Austria, UK, Belgium, Portugal, the Netherlands, and Italy. ${ }^{68}$ The strong position of Germany in both datasets reflects the situation observed for the Polish Constitutional Court. ${ }^{69}$ Similarly, the Polish Constitutional Court refers equally often to French case law as administrative courts. The distance between Germany, France and the third country of reference is also similar.

67 The countries not included in the graph are the following: Italy (21), Portugal (42), UK (21), USA (5), Japan (3), Malta (64), Montenegro (64), Czech Republic (14), Ireland (13), Canada (1), Austria (39), Romania (1), Serbia (1), Australia (1), Cyprus (19), Argentina (1), Malaysia (1), China (1), Spain (10), Greece (8), Luxemburg (9), Slovakia (2).

68 Norway (5), Switzerland (4), Croatia (2), Bulgaria (1), Denmark (5), Malta (1), Montenegro (1), Lithuania (2), Slovenia (2), Ireland (4), USA (4), Canada (1), Cyprus (2), Greece (2), Spain (3), Luxembourg (2), Slovakia (2), Japan (1), Romania (1), Serbia (1), Australia (1), Argentina (1), Malaysia (1), China (1).

69 J. Krzeminska-Vamvaka (n. 2). 
Fig. 5. Countries in comparative judgments 2010-2014

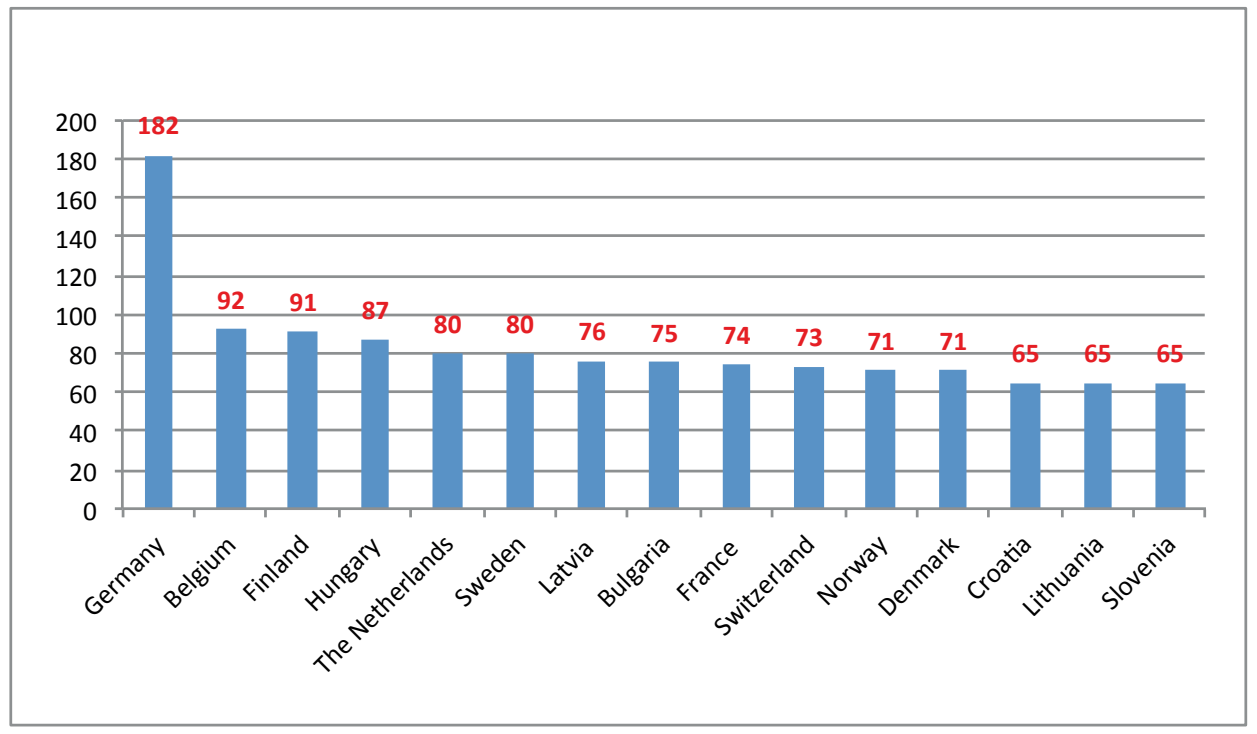

Fig. 6. Countries in comparative judgments 2010-2014

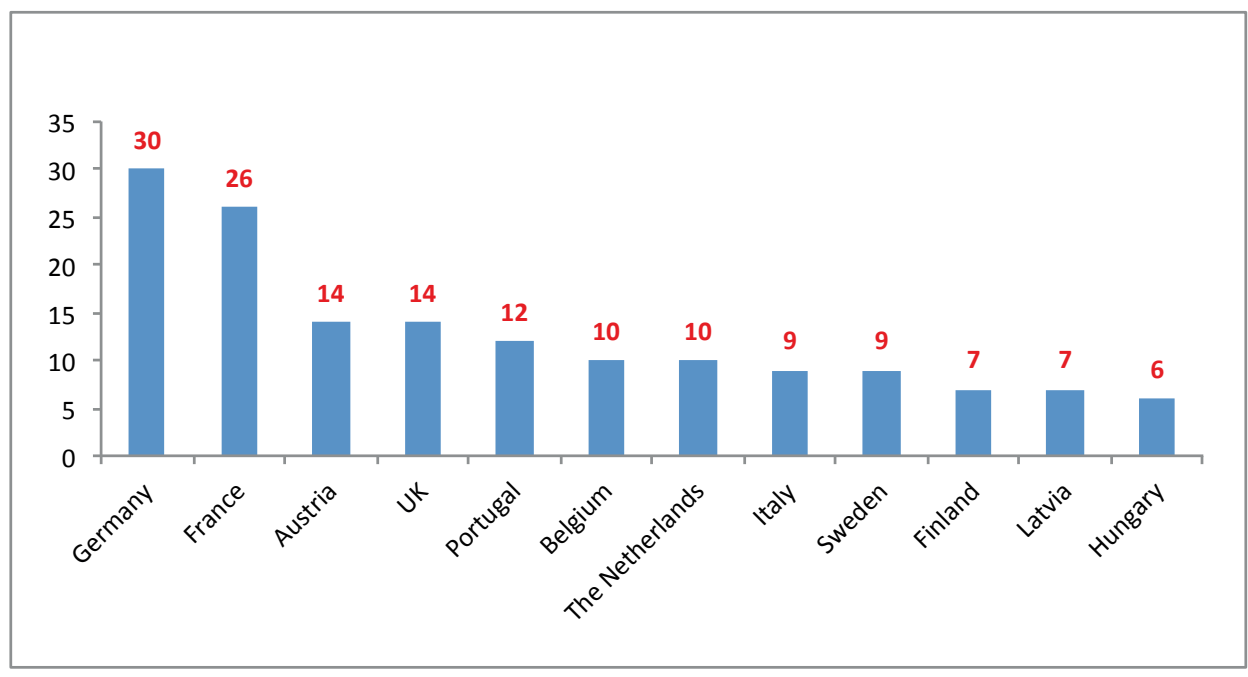




\subsection{Types of References}

Specificity, intensity and visibility of references are key concepts in analysing judicial comparativism. ${ }^{70}$ Intensity refers to the level of detail in the analysis of foreign law. It is strongly linked to visibility. The more detailed the analysis of foreign law, the more visible it becomes in the text of a judgment. A reference with low visibility will typically be very short and intertwined with the analysis of national law. Longer and typically more detailed analysis can be very visible, taking even a whole section of a judgment, dedicated to the analysis of foreign law. Specificity, finally, refers to the formal presentation of foreign law: is the court referring to the constitution of Germany or French law or is it including a precise reference to a German or French legislative act or a judgment?

Another way of categorizing comparative judgments is by a number of jurisdictions to which the court refers. In Poland, administrative courts typically refer to multiple legal systems. The same is true for the Polish Constitutional Court. ${ }^{71}$

Specificity, intensity and visibility as well as the number/variety of countries to which the national court refers, categorize comparative judgments by 'what' and 'how', i.e. by the content and the mechanics of the reference. Another important categorization criterion is 'why' national courts refer to foreign law. Foreign law can be used as an external authority (external source of legitimization) or as a source of inspiration. It is the why aspect of judicial comparativism that is the most controversial.

\subsection{Reasons for Resorting to Foreign Law}

The Polish administrative courts use foreign law mainly as a source of inspiration and external authority (external source of legitimization).

For instance, in case IFSK 375/12 the Polish administrative court stated that a judgment of a British court constituted an 'additional support' for the line of argumentation assumed. ${ }^{72}$ In another case, the court stated that in the light of examples from foreign law, a specific interpretation of Polish law was "all the more correct."73 Foreign law will also be used as a legitimizing tool in particularly controversial cases, like these concerning same sex-marriage. ${ }^{74}$

\footnotetext{
70 Ibidem, p. 32.

71 Ibidem, p. 22.

72 Case I FSK 375/12 (Supreme Administrative Court, 1 March 2013). References in this section are to judgments of the Polish Administrative Courts.

73 Case II GSK 1069/11 (Supreme Administrative Court, 30 August 2012).

74 Supreme Administrative Court cases: II FSK 2082/10 (20 March 2012), II FSK 2083/10 (20 March 2012).
} 
One of the primary reasons for resorting to foreign law will be linked to interpretation and implementation of EU law. ${ }^{75}$ Some references will jointly invoke foreign law and the European Convention on Human Rights. ${ }^{76}$

The courts might sometimes explicitly state that they refer to a particular country legislation or case law because that country's is an EU MS. ${ }^{77}$ Otherwise the reference is made to 'European States. ${ }^{78}$ Such references are practical inasmuch as the court draws both inspiration from the practice of other European States and reinforces a sense of belonging to the common European legal culture. Even if the administrative courts do not explicitly state that they refer to the practice of other European States, de facto, the references are almost exclusively made to other European (EU) States. Such 'European dimension' of comparative judgments is also very prominent in the comparative activity of the Polish Constitutional Court and evidences the need to stress a sense of belonging to the European legal culture in the post-communist era. ${ }^{79}$ In addition it is used as a strong legitimizing factor.

75 Gliwice Administrative Court cases: III SA/GI 393/14 (27 August 2014), III SA/GI 1938/11 (30 August 2011), III SA/GI 1939/11 (14 June 2012), III SA/GI 1940/11 (23 February 2012), III SA/GI 1935/11 (23 February 2012), III SA/GI 1936/11 (4 January 2012), III SA/GI 1937/11 (11 June 2012); Warsaw Administrative Court cases: III SA/Wa 1561/11 (22 July 2011), III SA/Wa 2081/12 (24 May 2012), III SA/Wa 990/12 (1 June 2012), III SA/Wa 486/12 (9 November 2012), III SA/Wa 862/12 (26 April 2012), III SA/Wa 1562/11 (22 July 2011), III SA/Wa 1536/11 (26 October 2011), III SA/Wa 1912/11 (17 January 2012), III SA/Wa 2476/12 (28 March 2012), II SA/Wa 2305/09 (10 March 2010), III SA/Wa 1974/09 (2 March 2010), III SA/Wa 2065/09 (2 March 2010), III SA/ Wa 1480/09 (2 March 2010), III SA/Wa 1973/09 (2 March 2010); case I SA/Po 1756/07 (Poznan Administrative Court, 30 May 2008).

76 Lublin Administrative Court cases: I SA/Lu 1053/13 (23 October 2013), I SA/Lu 896/10 (11 March 2011); case II FSK 2017/11 (Supreme Administrative Court, 5 July 2013).

77 Bydgoszcz Administrative Court cases: I SA/Bd 447/14 (19 November 2014), I SA/Bd 450/14 (18 February 2015), I SA/Bd 591/14 (18 February 2015), I SA/Bd 594/14 (14 July 2014), I SA/ Bd 354/14 (29 May 2014); Warsaw Administrative Court cases: III SA/Wa 997/14 (3 September 2014), III SA/Wa 1276/14 (3 July 2014), III SA/Wa 2476/12 (28 March 2013), III SA/Wa 640/13 (13 November 2013), III SA/Wa 1567/12 (16 January 2013), III SA/Wa 1450/09 (11 February 2010); Krakow Administrative Court cases: I SA/Kr 1529/13 (12 December 2013), I SA/Kr 1530/13 (12 December 2013), I SA/Kr 1528/13 (12 December 2013), I SA/Kr 1529/13 (12 December 2013), I SA/Kr 1530/13 (12 December 2013), I SA/Kr 1531/13 (12 December 2013), I SA/Kr 1750/11 (20 December 2011), I SA/Kr 2049/10 (17 February 2011); Gliwice Administrative Court cases: III SA/GI 2070/11 (27 June 2012); Supreme Administrative Court cases: I FSK 773/10 (12 May 2011), II OSK 1873/08 (12 February 2010); Wroclaw Administrative Court cases: I SA/Wr 935/12 (28 September 2012); Lodz Administrative Court cases: I SA/Ld 968/10 (21 December 2010), I SA/Ld 970/10 (21 December 2010), I SA/Ld 987/10 (21 December 2010), I SA/Ld 975/10 (21 December 2010), I SA/Ld 976/10 (21 December 2010), I SA/Ld 977/10 (21 December 2010), I SA/Ld 978/10 (21 December 2010).

78 Gliwice Administrative Court cases: III SA/GI 962/12 (16 October 2012), III SA/GI 960/12 (26 October 2012), III SA/GI 2434/10 (6 May 2011), III SA/GI 2166/10 (16 August 2011); Supreme Administrative Court: I FSK 1019/11 (8 January 2013), I FSK 1036/11 (9 May 2012). 


\subsection{Sources of Knowledge on Foreign Law}

In most cases the administrative courts refer directly to foreign law but without pointing to a specific source. In some cases a reference is made indirectly, through Polish comparative law scholarship. ${ }^{80}$ At other instances, the reference is made through quoting reports of the European Commission. ${ }^{81}$ There are also references to commentaries in foreign language. ${ }^{82}$

\subsection{Specificity}

Most of the comparative judgments provide a very general reference to foreign law by naming only a country at stake. In fact, many judgements offer a kaleidoscopic enumeration of different countries. ${ }^{83}$ In a number

80 See Warsaw Administrative Court cases: III SA/Wa 854/14 (6 October 2014), III SA/Wa 2272/11 (22 May 2012); Bydgoszcz Administrative Court cases: I SA/Bd 447/14 (19 November 2014), I SA/Bd 450/14 (12 November 2014), I SA/Bd 591/14 (12 November 2014), I SA/Bd 354/14 (5 November 2014); case I FSK 1019/11 (Supreme Administrative Court, 9 May 2012); case I SA/Wr 935/12 (Wroclaw Administrative Court, 28 September 2012).

81 Warsaw Administrative Court cases: III SA/Wa 997/14 (3 September 2014), III SA/Wa 1276/14 (3 July 2014); Krakow Administrative Court cases: I SA/Kr 1529/13 (12 December 2013), I SA/Kr 1530/13 (12 December 2013), I SA/Kr 1528/13 (12 December 2013), I SA/Kr 1529/13 (12 December 2013), I SA/Kr 1531/13 (12 December 2013), I SA/Kr 1533/13 (20 December 2013), I SA/Kr 1532/13 (20 December 2013), I SA/Kr 1534/13 (20 December 2013).

Gliwice Administrative Court cases: III SA/GI 1938/11 (14 June 2012), III SA/GI 1939/11 (14 June 2012), III SA/GI 1940/11 (14 June 2012), III SA/GI 1935/11 (11 June 2012), III SA/GI 1936/11 (11 June 2012), III SA/GI 1937/11 (11 June 2012).

83 Case III SA/Lu 376/13 (Lublin Administrative Court, 24 October 2014); Wroclaw Administrative Court cases: III SA/Wr 616/13 (19 December 2013), III SA/Wr 715/13 (12 December 2013), III SA/Wr 373/13 (4 October 2014), III SA/Wr 362/13 (9 October 2013), III SA/Wr 409/13 (26 September 2013), III SA/Wr 343/13 (3 October 2013), III SA/Wr 345/13 (3 October 2013), IIISA/Wr355/13(3October2013), IIISA/Wr413/13(26September2013),IIISA/Wr412/13(26September 2013), III SA/Wr 416/13 (26 September 2013), III SA/Wr 330/13 (26 September 2013), III SA/Wr 274/13 (19 September 2013), III SA/Wr 294/13 (19 September 2013), III SA/Wr 283/13 (19 September 2013), III SA/Wr 348/13 (5 September 2013), III SA/Wr 276/13 (21 August 2013), III SA/Wr 370/13 (21 August 2013), III SA/Wr 401/13 (21 August 2013), III SA/Wr 406/13 (21 August 2013), III SA/Wr 410/13 (21 August 2013), III SA/Wr 261/13 (21 August 2013), III SA/Wr 379/13 (21 August 2013), III SA/Wr 253/13 (21 August 2013), III SA/Wr 258/13 (28 June 2013), IIISA/Wr260/13 (28 June 2013), IIISA/Wr 123/13 (26 June2013), IIISA/Wr 198/13 (26 June2013), IIISA/Wr 296/13 (26 June 2013), IIISA/Wr 119/13 (26 June2013), IIISA/Wr 175/13 (26 June2013), III SA/Wr 182/13 (11 June 2013), III SA/Wr 181/13 (6 June 2013), III SA/Wr 174/13 (6 June 2013), III SA/Wr 190/13 (5 June 2013), III SA/Wr 202/13 (4 June 2013), III SA/Wr 195/13 (4 June 2013), III SA/Wr 150/13 (31 May 2013), III SA/Wr 120/13 (31 May 2013), III SA/Wr 121/13 (31 May 2013), III SA/Wr 151/13 (22 May 2013), III SA/Wr 152/13 (22 May 2013), III SA/Wr 83/13 (17 April 2013), IIISA/Wr88/13(17April2013),IIISA/Wr87/13(12April2013),IIISA/Wr49/13(4April 2013), III SA/Wr 52/13 (4 April 2013), III SA/Wr 89/13 (3 April 2013), III SA/Wr 41/13 (27 March 2013), III SA/Wr 51/13 (20 March 2013), III SA/Wr 14/13 (28 February 2013), III SA/Wr 
of cases the reference will be to a specific provision of foreign law or specific judgments of foreign courts. ${ }^{84}$

\subsection{Visibility and Intensity}

Since the majority of references are not specific, they will be typically intertwined with the analysis of national law. Visibility of analysis will typically go hand in hand with intensity. More detailed analysis will expand within the judgment and become more visible. ${ }^{85}$ Visibility of the reference to foreign law is an important parameter of judicial comparativism. Visible references demonstrate how open the courts are with their comparative approach. The same is true with regard to the comparative judgements of the Polish Constitutional Court as some judgments included even a comparative chapter.

496/12 (6 February 2013), III SA/Wr 495/12 (6 February 2013), III SA/Wr 15/13 (28 February 2013), III SA/Wr 5/13 (28 February 2013), III SA/Wr 13/13 (28 February 2013), III SA/Wr 4/13 (28 February 2013), III SA/Wr 493/12 (6 February 2013), III SA/Wr 494/12 (6 February 2013), III SA/Wr 535/12 (6 February 2013), III SA/Wr 534/12 (6 February 2013); Warsaw Administrative Court: III SA/Wa 1659/13 (14 November 2013), III SA/Wa 1660/13 (14 November 2013), III SA/Wa 3061/11 (14 September 2012), III SA/Wa 3062/11 (14 September 2012), III SA/Wa 3063/11 (4 September 2012), III SA/Wa 2476/12 (28 March 2013), III SA/Wa 1466/12 (17 January 2013), III SA/Wa 1476/12 (17 January 2013), III SA/Wa 1567/12 (16 January 2013), III SA/Wa 505/12 (15 January 2013), III SA/Wa 1197/12 (14 December 2012), III SA/Wa 1561/11 (28 June 2012), III SA/Wa 1562/11 (28 June 2012), III SA/Wa 1912/11 (28 June 2012); Krakow Administrative Court cases: I SA/Kr 1030/12 (17 September 2012), I SA/Kr 1031/12 (17 September 2012), I SA/Kr 1533/13 (20 December 2013), I SA/Kr 1532/13 (20 December 2013), I SA/Kr 1534/13 (20 December 2013); case II SA/Bd 524/13 (Bydgoszcz Administrative Court, 11 September 2013); Poznan Administrative Court cases: I SA/Po 788/12 (7 February 2013), III SA/Po 378/12 (6 December 2012), III SA/Po 379/12 (6 December 2012), III SA/Po 380/12 (6 December 2012), III SA/Po 381/12 (26 October 2012), III SA/Po 383/12 (25 September 2012); Opole Administrative Court cases: I SA/Op 271/12 (7 November 2012), I SA/Op 265/12 (21 June 2012), I SA/Op 266/12 (9 January 2013).

84 Gliwice Administrative Court cases: III SA/GI 393/14 (27 August 2014), III SA/GI 962/12 (16 October 2012), III SA/GI 960/12 (26 October 2012), III SA/GI 2166/10 (16 August 2011), III SA/ GI 2434/10 (6 May 2011); Warsaw Administrative Court cases: III SA/Wa 640/13 (13 November 2013), III SA/Wa 2476/13 (24 June 2014), III SA/Wa 1567/12 (16 January 2013), II SA/Wa 1562/11 (28 June 2012), III SA/Wa 1563/11 (28 June 2012), III SA/Wa 1912/11 (28 June 2012), III SA/Wa 2476/12 (28 March 2013), III SA/Wa 1271/10 (23 November 2010), III SA/Wa 1217/10 (4 February 2011); Lublin Administrative Court cases: I SA/Lu 1053/13 (23 October 2013), I SA/ Lu 896/10 (11 March 2011); Supreme Administrative Court cases: I FSK 375/12 (1 March 2013), II FSK 2017/11 (5 July 2013), II FSK 2082/10 (20 March 2012), II FSK 2083/10 (20 March 2012). Gliwice Administrative Court cases: III SA/GI 393/14 (27 August 2014), III SA/GI 962/12 (16 October 2012), II GSK 1069/11 (30 August 2012), III SA/GI 960/12 (26 October 2012), III SA/GI 2434/10 (16 August 2011), II SA/GI 2166/10 (16 August 2011). 


\subsection{Contributors to the Judicial Comparativism}

In the vast majority of cases, the administrative courts refer to foreign law seemingly on their own initiative. In some cases, parties to the proceedings invoke foreign law to support their position. ${ }^{86}$ Overall, the comparative activity is clearly driven by the administrative courts themselves.

\section{Administrative Courts Commenting on their Comparative Activity}

In most cases the Polish administrative courts do not comment on their comparative activity but simply refer to foreign law. They do not formally comment on the methodology used for their comparisons. This practice, unfortunately, is not unusual among courts citing foreign law. ${ }^{87}$

There are exceptions, however. In one case, a regional administrative court acknowledged that while it was not bound by the judgment of the German Federal Financial Court, it endorsed the position of that court in relation to the principle of uniform application of Union law in accordance with the case law of the CJEU. ${ }^{88}$ The Polish court supported how the German court ruled on the conformity of national provisions with Union law.

\section{Comparative Overview of CEE Judicial Dialogues in Administrative Law}

The CEE courts are in general receptive towards foreign influences. They are at the forefront of implementation of EU law and have also a significant exposure to cases with foreign element. It is a strong foundation for judicial comparativism.

86 Poznan Administrative Court cases: III SA/Po 1614/13 (17 December 2014), III SA/Po 1615/13 (17 December 2014), III SA/Po 1617/13 (17 December 2014), III SA/Po 1596/13 (6 November 2014), III SA/Po 1594/13 (6 November 2014), III SA/Po 1595/13 (6 November 2014), III SA/ Po 1555/13 (6 November 2014), III SA/Po 1556/13 (6 November 2014), III SA/Po 1557/13 (6 November 2014), III SA/Po 1558/13 (6 November 2014), III SA/Po 1597/13 (6 November 2014) (and a number of other decisions with an identical reference), II IV SA/Po 999/10 (12 May 2011); case II SA/Ld 845/13 (Lodz Administrative Court, 10 December 2013).

87 J. Krzemińska-Vamvaka (n. 2), p. 8; J. Waldron, 'Treating Like Cases Alike in the World: The Theoretical Basis of the Demand for Legal Unity', [in:] S. Muller, S. Richards (eds), Highest Courts and Globalisation (Hague Academic Press 2010), p. 100. 
The research conducted for the purposes this contribution demonstrates that in general the CEE courts are open to judicial dialogues and comparative approach.

One exception is the Curia of Hungary, which confirmed that except for the rulings of the CJEU, the administrative courts in practice do not invoke or refer to foreign judgments. ${ }^{89}$ Still, the references to the case law of the CJEU and the European Court of Human Rights are common.

The Latvian Supreme Court responded that references to foreign judgments do happen but by far not as often as the references to the case law of the CJEU, which is commonplace in the judgments of administrative courts. ${ }^{90}$ The references to foreign judgments would practically all be to judgments of German courts. This, according to the members of the Court, can be explained by the similarity of laws, as well as traditional interest in the German theory of administrative law. This is also in line with the strong position of Germany as a country of reference for the Polish administrative courts.

In Estonia, similarly as in Poland, there is no academic debate about judicial comparativism. ${ }^{91}$ Neither in relation to comparativism by administrative courts, nor, in fact, any other courts. Although specific comparative judgments by administrative courts could not be identified, the Estonian courts seem to consider foreign case law and scholarship when weighing possible legal interpretations. However, they do not explicitly point to that foreign case law and scholarship in their judgments. The situation is slightly different in criminal and civil law fields. The general part of the Estonian Criminal Code, for example, is largely based on the general part of the German Criminal Code. According to the information provided by the Legal and Information Department of the Supreme Court of Estonia, the relevant case law largely coincides with the German case law, although the Estonian courts would normally not include any specific reference to German law. Interestingly, however, in criminal cases, Estonian courts might refer to foreign commentaries. Similarly, in civil cases, judicial comparativism is more present. The Civil Chamber of the Supreme Court of Estonia established a principle that national courts can rely on foreign case law as long as there is no national case law concerning a specific question. This principle is mostly applied

89 Based on information provided by the court; the e-mail on file with the author (4 March 2015).

90 Based on information provided by the court; e-mail on file with the author (10 April 2015) references to the following examples were provided: case SKA-172/2007 (Latvian Supreme Court, 15 March 2007), in particular paras 14 and 15 (admissibility of evidence/administrative court's duty to establish facts in a dispute related to calculation of pension rights); case SKA-388/2007 (Latvian Supreme Court, 18 May 2007), in particular para. 17 (release to the owner of a car that was seized by authorities when the owner was caught smuggling excise goods); case SKA-524/2007 (Latvian Supreme Court, 6 November 2007), in particular paras 10 and 11.2, 14 (service in Latvian National Guard); case SKA-278/2010, (Latvian Supreme Court, 13 May 2010), in particular para. 13 (disciplinary punishment imposed on a notary).

91 Based on a reply provided by the Legal Information Department of the Supreme Court of Estonia. E-mail on file with the author (29 March 2015). 
in cases with international dimension (e.g. private international law, intellectual property law).

A very good case in point is the case 3-2-1-145-04. ${ }^{92}$ While the Civil Chamber of the Estonian Supreme Court confirmed there that foreign jurisprudence cannot be automatically 'taken over' and the case before it has to be solved on the basis of Estonian law, it accepted that the court may draw inspiration from relevant field of international law and recognized current practice. It referred to its earlier decision in case No. 3-2-1-9-03, where it held that similar laws in other states and the practice may be taken into account as reference material, for at least private law norms, for the purpose of ascertaining the meaning and purpose of the Act, even if they are not a ratio of private international law. This is particularly true in a situation where we have no implementing case law, but elsewhere an implementing case law related to a similar provision has settled. This applies in particular to the countries, which have a broadly similar legal system and the practice of the implementation of laws, particularly the European Union, the other Member States and in particular, European countries belonging to the European continental law family. In particular, it is necessary when interpreting and implementing the national law on the basis of the European Union law. ${ }^{93}$

According to the Estonian Supreme Court, there is room to apply a similar principle in administrative law cases, given that there are many areas in administrative law where there is international harmonization (in the EU: public procurement, environmental law). ${ }^{94}$

Indeed, comparative law is a backbone of different unification and harmonization processes. ${ }^{95}$ Those processes might concern specific subjects (e.g. international trade, international sale of goods ${ }^{96}$ ) or regions (notably the EU). Comparative study lies at the heart of those efforts because:

92 Judgment 3-2-1-145-04, 21 December 2004, available at <http://www.nc.ee/?id=11\&tekst=RK/3-2-1-145-04> (access: 17 May 2016), para. 39.

93 Case RT III 2003, 5, 57 (Estonian Supreme Court, 11 February 2003), <http://www.riigikohus. ee/?id=11\&tekst=RK/3-2-1-9-03> (access: 17 May 2016), para. 30. In that case the Civil Chamber of the Estonian Supreme Court held that disputes arising out of economic transactions have to be assessed on the basis of laws as well as customs and practices. In order to establish the international practice on warranty transactions, the applicant relied on UN 1995 Convention on independent guarantees and stand-by letters of credit and relevant explanations on Convention, as well as on International Chamber of Commerce's Uniform Rules for Demand Guarantees.

94 The Legal Information Department of the Estonian Supreme Court referred to publications like Juridica International, 'Learning from the Neighbours' Experiences: Property and Consumer Credit, <https://www.juridica.ee/juridica_en.php?document=en/articles/2014/8/244881.SUM. php> (access: 17 May 2016).

95 U.A. Mattei, T. Ruskola, A. Gidi, Schlesinger's Comparative Law, Cases-Text-Materials (Foundation Press 2009), p. 70.

96 See: United Nations Convention on Contracts for the International Sale of Goods <http://www. uncitral.org/pdf/english/texts/sales/cisg/V1056997-CISG-e-book.pdf> (access: 17 May 2016). 
the terms of any instruments aiming at international unification or harmonization of legal rules must be fitted into the substantive and procedural law of the participating countries. In consequence, the drafters of such instruments can do their work only on the basis of the most painstaking comparative studies. ${ }^{97}$

Legal harmonization is probably the most prominent example of a field where comparative method is used currently. Many scholarly projects in Europe explore the common core of legal principles and rules between European States. ${ }^{98}$ Proliferation of such projects demonstrates that European legal systems interact and share common features. Indeed, scholarly cooperation on specific projects has been strengthened by the creation of permanent structures like the European Law Institute. ${ }^{99}$ The CEE countries actively participate in those projects but are still underrepresented. ${ }^{100}$ Their participation in the associations of judges is much more noticeable. The openness towards foreign influences of the CEE courts is probably mainly manifested in activities of the courts' legal research offices.

The CEE countries have extensive experience with approximation of law. Foreign law has been used there as a source of inspiration in the transition process and legislative overhaul. The EU pre-accession process consisted primarily of approximation of national law to that of the EU. It is probably due to that past that the practice of looking at foreign law continues in those countries exists is readily admitted. For example, the Supreme Court of Estonia pointed out that foreign law is often thoroughly analysed in the legislative process and used as a source of inspiration. ${ }^{101}$ In the 2014 Annual Report of the Supreme Administrative Court of Lithuania, the President of the Court discusses how different

97 U.A. Mattei, T. Ruskola, A. Gidi, (n. 96), p. 72.

98 Examples include: Common Core of European Private Law <http://www.common-core.org> (access: 17 May 2016); M. Bussani, U. Mattei (eds), The Common Core of European Private Law Project (Cambridge University Press 2004); main features of the project are also described in U.A. Mattei, T. Ruskola, A. Gidi (n. 96), p. 221; Fundamental Rights and Private law in the European Union - G. Brueggemeier, A. Colombi-Ciacchi, G. Comande (eds), Fundamental Rights and Private Law in the European Union (Cambridge University Press 2010).

99 European Law Institute <https://www.europeanlawinstitute.eu/> (access: 17 May 2016).

100 For example, the representatives from CEE countries are clearly underrepresented among editors and national contributors for the on-going projects of the Common Core of European Private Law. See: <http://www.common-core.org/node/36> (access: 17 May 2016). The same conclusion can be drawn on the basis of the members and the steering committee of the Reneual <http://www.reneual.eu/> (access: 17 May 2016), where CEE countries are underrepresented.

101 The Legal Information Department of the Estonian Supreme Court referred to publications like Juridica International 'Learning from the Neighbours' Experiences: Property and Consumer Credit, <https://www.juridica.ee/juridica_en.php?document=en/articles/2014/8/244881. SUM.php> (access: 17 May 2016). See also: C. Dupré, Importing the Law in Post-Communist Transitions. The Hungarian Constitutional Court and the Right to Human Dignity (Hart Publishing 2003) and S. Belov, 'Russia: Foreign Transplants in the Russian Constitution and Invisible Foreign Precedents in Decisions of the Russian Constitutional Court', [in:] T. Groppi, 
legal systems influence each other and makes a highly interesting link between the process of transition and globalization. ${ }^{102}$ It is in fact a tribute to the comparative method. While the openness of the Lithuanian legislature and judiciary to foreign influences is rooted in transition, it continues today due to globalization. However, the limits to globalization-induced approximation are set by the need to preserve a national legal culture. As the President of the Lithuanian Court puts it "[a]lthough globalization creates economic and cultural integrity of the world's community, however, it does not set up uniformity of nations." 103 Therefore, another way to see the limits of absorption of foreign influences is a balance between tradition and innovation.

There are therefore two main axes of comparative activity: global problems (technology, environment) that call for global solutions and fundamental principles of democracy and human rights protection. As far as the latter is concerned, the ECHR ${ }^{104}$ is a prominent example of core standards for protection of human rights and fundamental freedoms across Europe. Courts across CEE region readily refer to the Convention and probably the most visible comparative cases are those in the area of human rights. ${ }^{105}$

\section{Conclusions}

The growth of a structured transnational co-operation between administrative judges lays strong foundations for transnational judicial borrowings. While the CEE courts confirm that they are open to judicial dialogues and comparativism, it is not always confirmed by the actual references to foreign law in their judgments. If such references can be identified, they evidence a practice that is spontaneous and thus unsystematized and undisciplined. The Polish administrative courts do not formally comment on the methodology used for their comparisons.

M.C. Ponthoreau (eds), The Use of Foreign Precedents by Constitutional Judges (Hart Publishing 2013), p. 347.

102 Supreme Administrative Court of Lithuania, 'Annual Report 2014', <http:// www.lvat.lt/download/1952/metinis_2014-en-web.pdf> (access: 17 May 2016) 2.

103 Ibidem, p. 3.

104 Convention for the Protection of Human Rights and Fundamental Freedoms (European Convention on Human Rights, as amended) (ECHR).

105 For example, for Poland see: J. Krzemińska-Vamvaka (n. 2); for Russia see: A. Trochev, Judging Russia: The Role of the Constitutional Court in Russian Politics 1990-2006 (Oxford 2011), p. 44; S. Marochkin, 'International Law in the Courts of the Russian Federation. Practice of Application' (2007) 6 Chinese Journal of International Law 2, p. 341. 
It is not unusual among courts citing foreign law. ${ }^{106}$ Exceptionally, the Civil Chamber of the Estonian Supreme Court did define a general methodological framework for judicial comparativism, which can be transferred to the field of administrative law.

Of course, judicial comparativism is target of the same theoretical criticisms as comparative law in general (limited role of theory in comparative law). ${ }^{107}$ Those methodological criticisms are more pertinent in the case of the CEE countries where academic underpinnings of comparative law are not well developed. Although in the interwar period, comparative law had quite a tradition in Poland, ${ }^{108}$ it was significantly crippled during the communism. ${ }^{109}$ While the comparative law experienced a revival after 1989, mainly due to the international dimension of the transition process, there is still a mismatch between the practice and the theory. Comparative law is extensively used in legislating and by the judiciary, ${ }^{110}$ but it is quite underdeveloped in academia. ${ }^{111}$ The lack of scholarly discussion reflects the lack of theoretical underpinnings for the judicial comparativism. Indeed, the rules governing the selection of foreign law are desirable to make sure that judicial comparativism is not selective and arbitrary.

Those CEE courts that engage in a (visible) comparative activity recognize that foreign law has no binding force domestically but it is a useful source of inspiration or confirmation for possible legal interpretations. In the field of implementation of EU law, judicial comparativism can bring significant efficiency gains. Courts can save scarce and valuable resources by drawing inspiration and taking information from their foreign EU counterparts that faced a similar legal problem. If a problem is new for a specific country, it can draw from the wealth of practical information abroad on practical consequences and experiences with a particular solution. The access to information on various possible approaches to the same problem that were tested in practice is invaluable. This is probably why the CEE countries engaged in the practice of judicial comparativism when faced with major legislative overhauls and the process of harmonization to EU requirements.

106 J. Krzemińska-Vamvaka (n. 2), p. 8; J. Waldron, 'Treating Like Cases Alike in the World: The Theoretical Basis of the Demand for Legal Unity', [in:] S. Muller, S. Richards (eds), Highest Courts and Globalisation (Hague Academic Press 2010), p. 100.

107 G. Frankenberg (n. 62), p. 416.

108 In the interwar period, as the codification and unification processes were underway, law practitioners had to cope on a daily basis with several legal systems in force simultaneously. After 1918, depending on the region and branch of law, up to 5 different legal systems were in force in Poland (French, Austrian, German, Russian, Hungarian). This was due to the prewar division of the Polish territory; see: J. Bardach, B. Lesnodorski, M. Pietrzak, Historia ustroju i prawa polskiego (PWN 1994), p. 461, in particular, p. 552.

109 Z. Kuhn, 'Development of Comparative Law in Central and Eastern Europe', [in:] M. Reimann, R. Zimmermann (eds), The Oxford Handbook of Comparative Law (Oxford University Press 2006), p. 215.

110 For the Polish Constitutional Court see: J. Krzemińska-Vamvaka (n. 2).

111 Z. Kuhn (n. 110), p. 235. 
Judicial comparativism, or comparative approach in general, represented significant efficiency gains in the fast-changing environment of transition.

The potential for efficiency gains for courts goes beyond the implementation of EU law. The legal borders between countries become more and more porous because of the growing legal convergence due to interlinkages between economies and transnational problems that call for uniform transnational solutions.

The fact that the CEE countries have been receptive towards foreign influences and engaged in judicial comparativism spontaneously constitutes a valuable experience. While the judicial comparativism can bring gains to courts beyond the CEE region, that region has an untapped potential to transform a spontaneous practice into a methodologically sound exercise. Practical experiences of recent times evidence gains and traps of judicial comparativism. From a methodological point of view, it is important to preserve the integrity of a legal system. A systemized approach and a more systemic knowledge of foreign legal systems are key to striking a balance between the ever-growing legal convergence and national legal identity. 


\section{Bibliography}

\section{Case Law}

\section{Poland}

\section{The Supreme Administrative Court}

I FSK 773/10 (12 May 2011)

II FSK 2082/10 (20 March 2012)

II FSK 2083/10 (20 March 2012)

I FSK 1019/11 (9 May 2012)

I FSK 1036/11 (9 May 2012)

II GSK 1069/11 (30 August 2012)

I FSK 1019/11 (8 January 2013)

I FSK 375/12 (1 March 2013)

II FSK 2017/11 (5 July 2013)

\section{Bydgoszcz Administrative Court}

II SA/Bd 524/13 (11 September 2013)

I SA/Bd 354/14 (29 May 2014)

I SA/Bd 594/14 (14 July 2014)

I SA/Bd 354/14 (5 November 2014)

I SA/Bd 450/14 (12 November 2014)

I SA/Bd 591/14 (12 November 2014)

I SA/Bd 447/14 (19 November 2014)

I SA/Bd 450/14 (18 February 2015)

I SA/Bd 591/14 (18 February 2015)

\section{Gliwice Administrative Court}

III SA/Gl 2434/10 (6 May 2011)

III SA/Gl 2166/10 (16 August 2011)

III SA/Gl 2434/10 (16 August 2011)

III SA/Gl 1938/11 (30 August 2011)

III SA/Gl 1936/11 (4 January 2012)

III SA/Gl 1935/11 (23 February 2012)

III SA/Gl 1940/11 (23 February 2012)

III SA/Gl 2070/11 (27 June 2012)

III SA/Gl 1935/11 (11 June 2012)

III SA/Gl 1936/11 (11 June 2012)

III SA/Gl 1937/11 (11 June 2012)

III SA/Gl 1938/11 (14 June 2012) 
III SA/Gl 1939/11 (14 June 2012)

III SA/Gl 1940/11 (14 June 2012)

II GSK 1069/11 (30 August 2012)

III SA/Gl 962/12 (16 October 2012)

III SA/Gl 960/12 (26 October 2012)

III SA/Gl 393/14 (27 August 2014)

\section{Krakow Administrative Court}

I SA/Kr 2049/10 (17 February 2011)

I SA/Kr 1750/11 (20 December 2011)

I SA/Kr 1030/12 (17 September 2012)

I SA/Kr 1031/12 (17 September 2012)

I SA/Kr 1528/13 (12 December 2013)

I SA/Kr 1529/13 (12 December 2013)

I SA/Kr 1530/13 (12 December 2013)

I SA/Kr 1531/13 (12 December 2013)

I SA/Kr 1532/13 (20 December 2013)

I SA/Kr 1533/13 (20 December 2013)

I SA/Kr 1534/13 (20 December 2013)

\section{Lublin Administrative Court}

I SA/Lu 896/10 (11 March 2011)

I SA/Lu 1053/13 (23 October 2013)

III SA/Lu 376/13 (24 October 2014)

\section{Lodz Administrative Court}

I SA/Ld 968/10 (21 December 2010)

I SA/Ld 970/10 (21 December 2010)

I SA/Ld 975/10 (21 December 2010)

I SA/Ld 976/10 (21 December 2010)

I SA/Ld 977/10 (21 December 2010)

I SA/Ld 978/10 (21 December 2010)

I SA/Ld 987/10 (21 December 2010)

II SA/Ld 845/13 (10 December 2013)

\section{Opole Administrative Court}

I SA/Op 265/12 (21 June 2012)

I SA/Op 271/12 (7 November 2012)

I SA/Op 266/12 (9 January 2013)

\section{Poznan Administrative Court}

I SA/Po 1756/07 (30 May 2008)

II IV SA/Po 999/10 (12 May 2011) 
III SA/Po 383/12 (25 September 2012)

III SA/Po 381/12 (26 October 2012)

III SA/Po 378/12 (6 December 2012)

III SA/Po 379/12 (6 December 2012)

III SA/Po 380/12 (6 December 2012)

I SA/Po 788/12 (7 February 2013)

III SA/Po 1596/13 (6 November 2014)

III SA/Po 1614/13 (17 December 2014)

III SA/Po 1615/13 (17 December 2014)

III SA/Po 1617/13 (17 December 2014)

III SA/Po 1555/13 (6 November 2014)

III SA/Po 1556/13 (6 November 2014)

III SA/Po 1557/13 (6 November 2014)

III SA/Po 1558/13 (6 November 2014)

III SA/Po 1594/13 (6 November 2014)

III SA/Po 1595/13 (6 November 2014)

III SA/Po 1597/13 (6 November 2014)

\section{Warsaw Administrative Court}

III SA/Wa 1450/09 (11 February 2010)

III SA/Wa 1480/09 (2 March 2010)

III SA/Wa 1973/09 (2 March 2010)

III SA/Wa 1974/09 (2 March 2010)

III SA/Wa 2065/09 (2 March 2010)

II SA/Wa 2305/09 (10 March 2010)

III SA/Wa 1271/10 (23 November 2010)

III SA/Wa 1217/10 (4 February 2011)

III SA/Wa 1561/11 (22 July 2011)

III SA/Wa 1562/11 (22 July 2011)

III SA/Wa 1536/11 (26 October 2011)

III SA/Wa 1912/11 (17 January 2012)

III SA/Wa 2476/12 (28 March 2012)

III SA/Wa 862/12 (26 April 2012)

III SA/Wa 2272/11 (22 May 2012)

III SA/Wa 2081/12 (24 May 2012)

III SA/Wa 990/12 (1 June 2012)

III SA/Wa 1561/11 (28 June 2012)

III SA/Wa 1562/11 (28 June 2012)

III SA/Wa 1563/11 (28 June 2012)

III SA/Wa 1912/11 (28 June 2012)

III SA/Wa 3061/11 (14 September 2012)

III SA/Wa 3062/11 (14 September 2012)

III SA/Wa 3063/11 (4 September 2012) 
III SA/Wa 486/12 (9 November 2012)

III SA/Wa 1197/12 (14 December 2012)

III SA/Wa 505/12 (15 January 2013)

III SA/Wa 1567/12 (16 January 2013)

III SA/Wa 1466/12 (17 January 2013)

III SA/Wa 1476/12 (17 January 2013)

III SA/Wa 2476/12 (28 March 2013)

III SA/Wa 640/13 (13 November 2013)

III SA/Wa 1659/13 (14 November 2013)

III SA/Wa 1660/13 (14 November 2013)

III SA/Wa 2476/13 (24 June 2014)

III SA/Wa 1276/14 (3 July 2014)

III SA/Wa 997/14 (3 September 2014)

III SA/Wa 854/14 (6 October 2014)

\section{Wroclaw Administrative Court}

I SA/Wr 935/12 (28 September 2012)

III SA/Wr 493/12 (6 February 2013)

III SA/Wr 494/12 (6 February 2013)

III SA/Wr 495/12 (6 February 2013)

III SA/Wr 496/12 (6 February 2013)

III SA/Wr 535/12 (6 February 2013)

III SA/Wr 534/12 (6 February 2013)

III SA/Wr 4/13 (28 February 2013)

III SA/Wr 5/13 (28 February 2013)

III SA/Wr 13/13 (28 February 2013)

III SA/Wr 14/13 (28 February 2013)

III SA/Wr 15/13 (28 February 2013)

III SA/Wr 41/13 (27 March 2013)

III SA/Wr 51/13 (20 March 2013)

III SA/Wr 89/13 (3 April 2013)

III SA/Wr 49/13 (4 April 2013)

III SA/Wr 52/13 (4 April 2013)

III SA/Wr 87/13 (12 April 2013)

III SA/Wr 83/13 (17 April 2013)

III SA/Wr 88/13 (17 April 2013)

III SA/Wr 151/13 (22 May 2013)

III SA/Wr 152/13 (22 May 2013)

III SA/Wr 120/13 (31 May 2013)

III SA/Wr 121/13 (31 May 2013)

III SA/Wr 150/13 (31 May 2013)

III SA/Wr 195/13 (4 June 2013)

III SA/Wr 202/13 (4 June 2013) 
III SA/Wr 190/13 (5 June 2013)

III SA/Wr 174/13 (6 June 2013)

III SA/Wr 181/13 (6 June 2013)

III SA/Wr 182/13 (11 June 2013)

III SA/Wr 119/13 (26 June 2013)

III SA/Wr 123/13 (26 June 2013)

III SA/Wr 175/13 (26 June 2013)

III SA/Wr 198/13 (26 June 2013)

III SA/Wr 296/13 (26 June 2013)

III SA/Wr 258/13 (28 June 2013)

III SA/Wr 260/13 (28 June 2013)

III SA/Wr 253/13 (21 August 2013)

III SA/Wr 261/13 (21 August 2013)

III SA/Wr 276/13 (21 August 2013)

III SA/Wr 370/13 (21 August 2013)

III SA/Wr 379/13 (21 August 2013)

III SA/Wr 401/13 (21 August 2013)

III SA/Wr 406/13 (21 August 2013)

III SA/Wr 410/13 (21 August 2013)

III SA/Wr 348/13 (5 September 2013)

III SA/Wr 274/13 (19 September 2013)

III SA/Wr 283/13 (19 September 2013)

III SA/Wr 294/13 (19 September 2013)

III SA/Wr 409/13 (26 September 2013)

III SA/Wr 412/13 (26 September 2013)

I III SA/Wr 413/13 (26 September 2013)

III SA/Wr 416/13 (26 September 2013)

III SA/Wr 330/13 (26 September 2013)

II SA/Wr 343/13 (3 October 2013)

III SA/Wr 345/13 (3 October 2013)

III SA/Wr 355/13 (3 October 2013)

III SA/Wr 362/13 (9 October 2013)

III SA/Wr 715/13 (12 December 2013)

III SA/Wr 616/13 (19 December 2013)

III SA/Wr 373/13 (4 October 2014)

\section{Estonia}

\section{Estonian Supreme Court}

RT III 2003, 5, 57, <http://www.riigikohus.ee/?id=11\&tekst=RK/3-2-1-9-03> (access: 17 May 2016) 


\section{Latvia}

\section{Latvian Supreme Court}

SKA-172/2007 (15 March 2007)

SKA-388/2007 (18 May 2007)

SKA-524/2007 (6 November 2007)

SKA-278/2010 (13 May 2010)

\section{International Legal Sources}

Convention for the Protection of Human Rights and Fundamental Freedoms (European Convention on Human Rights, as amended) (ECHR)

United Nations Convention on Contracts for the International Sale of Goods (Vienna 1980) (CISG), $<$ http://www.uncitral.org/pdf/english/texts/sales/cisg/CISG.pdf> (access: 17 May 2016)

\section{References}

\section{Books}

Bardach J., Lesnodorski B., Pietrzak M., Historia ustroju i prawa polskiego (PWN 1994)

Bussani M., Mattei U. (eds), The Common Core of European Private Law Project (Cambridge University Press 2004)

Cruz de P., Comparative Law in a Changing World ( $3^{\text {rd }}$ Edition, Routledge-Cavendish 2007)

Dupré C., Importing the Law in Post-Communist Transitions. The Hungarian Constitutional Court and the Right to Human Dignity (Hart Publishing 2003)

Markesinis B., Fedtke J., Judical Recourse to Foreign Law. A New Source of Inspiration? (Routledge 2007) 61

Secondat de C. (Baron de Montesquieu), The Spirit of Laws (Kindle Edition, Location 251-259 of 10328), Halcyon Classic Series 1752

Trochev A., Judging Russia: The Role of the Constitutional Court in Russian Politics 1990-2006 (Oxford 2011)

Waldron J., Partly Laws Common to All Mankind: Foreign Law in American Courts (Location 4130 of 8217, Kindle Edition, Yale University Press 2012)

Zweigert K., Koetz H., Introduction to Comparative Law (Clarendon Press Oxford 1998)

\section{Book Sections}

Belov S., 'Russia: Foreign Transplants in the Russian Constitution and Invisible Foreign Precedents in Decisions of the Russian Constitutional Court', [in:] Groppi T., Ponthoreau M.C. (eds), The Use of Foreign Precedents by Constitutional Judges (Hart Publishing 2013)

Brueggemeier G., Colombi-Ciacchi A., Comande G. (eds), Fundamental Rights and Private Law in the European Union (Cambridge University Press 2010)

Kuhn Z., 'Development of Comparative Law in Central and Eastern Europe', [in:] Reimann M., Zimmermann R. (eds), The Oxford Handbook of Comparative Law (Oxford University Press 2006) 
Mattei U.A., Ruskola T., Gidi A., Schlesinger's Comparative Law, Cases-Text-Materials (Foundation Press 2009)

Waldron J., 'Treating Like Cases Alike in the World: The Theoretical Basis of the Demand for Legal Unity', [in:] Muller S., Richards S. (eds), Highest Courts and Globalisation (Hague Academic Press 2010)

\section{Journal Articles}

Frankenberg G., 'Critical Comparisons: Re-thinking Comparative Law' (1985) 26 Harvard International Law Journal 411

Khan-Freund O., 'On Uses and Misuses of Comparative Law' (1974) 37 Modern Law Review 277

Marochkin S., 'International Law in the Courts of the Russian Federation. Practice of Application' (2007) 6 Chinese Journal of International Law 2341

Posner R.A., 'Foreword: A Political Court' (2005) 119 Harvard Law Review 31

Tushnet M., 'The Possibilities of Comparative Constitutional Law' (1999) 108 Yale Law Journal 1225

\section{Other}

Juridica International 'Learning from the Neighbours' Experiences: Property and Consumer Credit, <https://www.juridica.ee/juridica_en.php?document=en/articles/2014/8/244881.SUM.php> (access: 17 May 2016)

Kingsbury B., Krisch N., Stewart R., 'The Emergence of Global Administrative Law' (Global Administrative Law Project 2005), <http://www.iilj.org/wp-content/uploads/2016/08/Kingsbury-etal-The-Emergence-of-Global-Administrative-Law-2004-2.pdf> (access: 17 May 2016)

Krzeminska-Vamvaka J., 'Courts as Comparatists: References to Foreign Law in the case-law of the Polish Constitutional Court' (2012) Jean Monnet Working Paper 05/12, <http://www.jeanmonnetprogram. org/wp-content/uploads/2014/12/JMWP05Krzeminska-Vamvaka.pdf> (access: 17 May 2016)

Thibaut E., 'Presentation of the JuriFast Project', <http://www.aca-europe.eu/seminars/2014_Brno/ RT2_JuriFast_THIBAUT_EN.pdf> (access: 17 May 2016)

\section{Websites}

The Consultative Council of European Judges Homepage <http://www.coe.int/t/DGHL/cooperation/ccje/default_en.asp> (access: 17 May 2016)

The Curia Homepage, 'International Relations', <http://www.lb.hu/en/english/international-relations> (access: 17 May 2016)

Eurojust Homepage <http://eurojust.europa.eu/Pages/home.aspx> (access: 17 May)

The European Commission for the Efficiency of Justice Homepage <http://www.coe.int/T/dghl/cooperation/cepej/default_en.asp> (access: 17 May 2016)

The European Judicial Network in civil and commercial matters Homepage <http://ec.europa.eu/ civiljustice/index_en.htm> (access: 17 May 2016)

The European Judicial Training Network Homepage <http://www.iojt.org > (access: 17 May 2016)

European Law Institute <https://www.europeanlawinstitute.eu/> (access: 17 May 2016)

European University Institute Centre for Judicial Cooperation, 'Case Law Database', <http://www.eui. eu/Projects/CentreForJudicialCooperation/CJCDatabase/Database.aspx> (access: 17 May 2016)

The Estonian Supreme Court Homepage <http://www.riigikohus.ee/?id=1291> (access: 17 May 2016) 
The International Organization for Judicial Training Homepage <http://www.iojt.org/iojt2/index. html> (access: 17 May 2016)

The Latvian Supreme Court Homepage, 'Joining the European Judiciary', <http://at.gov.lv/en/ the-history/joining-the-european-judiciary/> (access: 17 May 2016)

The Lithuanian Supreme Administration Court, 'The National and International Cooperation', $<$ http://www.lvat.lt/en/national-and-international-cooperation.html> (access: 17 May 2016)

The Network of the Presidents of the Supreme Courts <http://www.network-presidents.eu/> (access: 17 May 2016)

The Polish Supreme Administrative Court Homepage, 'Współpraca Międzynarodowa', <http://www. nsa.gov.pl/wspolpraca-miedzynarodowa-1.php> (access: 17 May 2016)

The Slovakian Supreme Court Homepage, 'International activities', <http://www.nssr.gov.sk/international-activities/> (access: 17 May 2016)

The Venice Commission Homepage <http://www.venice.coe.int> (access: 17 May 2016) 